\title{
Peningkatan Kemampuan Usaha Kecil Menengah Di Wilayah Bandung Raya Dalam PemanfaAatan InTernet Sebagai Sarana Pemasaran Dan Perluasan Jangkauan Pasar
}

\author{
${ }^{1}$ Djamaludin, ${ }^{2}$ Aviasti, ${ }^{3}$ Asep Nana Rukmana, ${ }^{4}$ Otong Rukmana \\ ${ }^{1}$ Program Studi Teknik Industri Universitas Islam Bandung, Jl. Tamansari No. 1 Bandung 40116 \\ e-mail: ${ }^{1}$ mas.jamal@gmail.com
}

\begin{abstract}
Abstrak. Usaha Kecil dan Menengah khususnya di bidang Industri Kreatif pada saat ini dan yang akan datang dapat dijadikan andalan bagi peningkatan pendapatan masyarakat dan negara, dikarenakan lebih bertumpu pada kemampuan dan kreatifitas sumber daya manusia yang dimiliki oleh daerah masing-masing. Program PKM yang dilakukan ditujukan untuk peningkatan omset dan perluasan pasar usaha kecil industri kreatifdi lingkungan Kota Cimahi dan Bandung, melalui alih pengetahuan dan teknologi dalam hal perancangan dan pembuatan bisnis secara online, pemanfaatan Jejaring E-Commerce yang sudah ada dan berskala besarbaik yang bersifat nasional maupun internasional, pemanfaatan transaksi perbankan secara online, Penggunaan Social Media dan Search Engine Optimization (SEO) dalam penjualan dan pemasaran secara online. Diharapkan dengan terselenggaranya pelatihan ini dapat meningkatkan jangkauan pasar dan jaringan bisnis berbasis internet baik lokal, nasional maupun internasional bagi pelaku usaha di Kota Cimahi, Kota Bandung dan Propinsi Jawa Barat pada umumnya.
\end{abstract}

Kata kunci: Usaha Kecil Menengah, Perluasan Pasar, Jejaring E-Commerce, Social Media

\section{Pendahuluan}

Pertumbuhan penguna internet di Indonesia terus tumbuh. Menurut survey yang dilakukan oleh Asosiasi Penyelenggara Jasa Internet Indonesia (APJII), pada tahun 2012 diketahui terdapat 63 juta Pengguna internet di Indonesia, dengan kenaikan sekitar $20 \%$ pada tahun 2013. Peningkatan itu, akan terjadi seiring transformasi dan perkembangan teknologi 4G, termasuk Wimax dan LTE, Fiber To The Home (FTTH), dan spektrum tambahan $3 \mathrm{G}$ untuk operator. Dengan pengguna internet yang sedemikian besar, namun pemanfaatan perdagangan elektronik (E-Commerce) sebagai sarana penjualan hanya dilakukan oleh kurang dari 5\% pengguna internet. Oleh karena itu peluang yang sedemikian besar harus mampu dimanfaatkan oleh Usaha Kecil Menengah (UKM) / Industri Kecil Menengah (IKM ) khususnya di bidang industri kreatif sebagai upaya peningkatan daya saing, daya serap dan perluasan pasar.

Peran UKM terhadap pertumbuhan perekonomian Indonesia, telah dapat dibuktikan pada pasca krisis tahun 1997 di Indonesia, UKM dapat menjadi tumpuan bagi perekonomian nasional. Hal ini dikarenakan UKM mampu bertahan dibandingkan dengan usaha besar lainnya yang cenderung mengalami keterpurukan. Hal tersebut dibuktikan dengan semakin bertambahnya jumlah UKM setiap tahunnya. UKM di negara berkembang hampir selalu merupakan kegiatan ekonomi yang terbesar dalam jumlah dan kemampuannya dalam menyerap tenaga kerja. Begitu pula dengan kondisi yang ada di Indonesia, meskipun dalam ukuran sumbangan terhadap PDB belum cukup tinggi, sektor ini dapat tetap menjadi tumpuan bagi stabilitas ekonomi nasional. 
Sehingga perannya diharapkan dapat menciptakan kesejahteraan kepada masyarakat Indonesia.

Teknologi Internet dapat digunakan sebagai media pemasaran yang efektif, dengan jangkauan yang sangat luas tidak terbatas oleh ruang dan waktu. Oleh karena itu para pelaku usaha kecil dan menengah harus memanfaatkannya sebagai sarana untuk meningkatkan jangkauan pasar, baik tingkat nasional maupun internasional.

Berdasarkan hal tersebut diatas maka Pengabdian Kepada Masyarakat (PKM) ini melaksanakan pelatihan dan berbagi pengetahuan terkait "Bagaimana pemanfaatan internet oleh pelaku usaha UKM/IKM sebagai media pemasaran untuk perluasan jangkauan pasar baik secara nasional maupun internasional".

Adapun tujuan yang ingin dicapai dari PKM ini adalah memberikan kemampuan yang maksimal bagi pelaku usaha kecil dalam pemanfaatan internet sebagai media pemasaran untuk perluasan pasar secara nasional dan internasional.

Hasil dari PKM ini diharapkan akan membawa dampak positif sebagai berikut (1) Peningkatan daya saing UKM di wilayah Bandung Raya dan sekitarnya (2) Peningkatan jangkauan pasar bagi pelaku usaha UKM/IKM di wilayah Bandung Raya dan sekitarnya; (3) Percontohan bagi pelaku UKM/IKM lainnya di Indonesia dalam pemanfaatan internet sebagai media pemasaran. (4) Program yang berkelanjutan dalam peningkatan kapasitas pemanfaatan teknologi digital bagi pelaku UKM/IKM DI seluruh Indonesia.

Strategi bisnis dalam pemasaran dan promosi produk UKM Dengan media sosial internet merupakan salah satu hal yang perlu di lakukan dalam upaya memperluas jejaring pasar baik di tingkat lokal, nasional maupun internasional.dan Dengan memahami strategi Bisnis dalam pemasaran dan promosi produk UKM Dengan media sosial di internet, strategi online marketing membuat usaha seakan akan 24 jam non stop dan dapat di akses seluruh dunia dan tidak banyak mengeluarkan banyak biaya.

Sehingga para pelaku UKM/IKM perlu untuk memahami dan mempraktekan terkait (1) Strategi Online Marketing melalui Website atau Blog, (2) Strategi pemasaran optimasi website, (3) Pemanfaatan Jejaring Sosial dan email marketing, (4) Pengelolaan Forum atau Komunitas Online, (5) Promosi melalui iklan gratis, (6) Pemasangan banner di situs lain, (7)Review produk, (8) kemampuan memberikan respon terhadap permintaan dan keluhan pelanggan (8) kemudahan website terindeks oleh mesin pencari GOOGLE (9) Pemanfaatan jejaring pasar berbasis internet (emarket place) baik lokal, nasional maupun internasional.

\section{Kajian Pustaka}

Strategi bisnis dalam pemasaran dan promosi produk UKM Dengan media sosial internet merupakan salah satu hal yang patut di lakukan. Menarik memang, meningkatnya pengguna internet saat ini ternyata tidak di abaikan begitu saja oleh para pelaku bisnis. Saat ini banyak pelaku bisnis yang sengaja membuat website, blog, atau social network seperti facebook dan twitter sebagai media pemasaran produk mereka. Kekuatan media internet yang cukup besar, memberikan keuntungan tersendiri bagi pelaku usaha. Dengan memahami strategi Bisnis dalam pemasaran dan promosi produk UKM Dengan media social internet, strategi online marketing membuat usaha seakan akan 24 jam non stop dan dapat di akses seluruh dunia dan tidak banyak mengeluarkan banyak biaya. 
a. Strategi Online Marketing via Website atau Blog.

Memiliki website atau blog sebagai sarana pemasaran secara online adalah keharusan, karena dengan memiliki wesite atau blog, usaha anda dapat terlihat secara online dalam 24 jam, dan dapat di akses oleh seluruh dunia, terlebih lagi website atau blog bisa anda buat lebih detail produk yang anda jual.

b. Strategi pemasaran optimasi website

Lebih banyak pengguna internet mencari suatu informasi melalui search engine seperti Google dan Yahoo Sesuai dengan keyword atau kata kunci yang di inginkan atau di kenal dengan istilah SE (Search Engine Optimization). Umumnya pengguna akan mengklik link teratas tau di halaman pertama saja dari hasil pencarian.

c. Manfaat Jaringan Sosial

Hampir semua pengguna internet mempunyai akun di situs jejaring social seperti facebook, twitter, Friendster, dan social network lainnya. Saat ini pengguna facebook atau twitter saja sudah hampir puluhan juta dari Indonesia saja,nah sampai saat ini istilah facebook marketing sangat berpotensi untuk mempromosikan produk.

\section{d. Email Marketing}

Selain melakukan promosi dari website, blog, social network, ternyata cara satu ini juga cukup ampuh dilakukan untuk promosi marketing. Anda dapat memberi tahu pada calon customer anda tentang informasi produk anda, memberikan penawaran secara masal maupun personal melalui email marketing. Sehingga kegiatan promosi semakin mudah, murah, dan efektif. Calon customer yang tertarik dengan produk anda, biasanya akan menanyakan informasi produk tersebut melalui telepon maupun membalas email anda. Keberadaan email marketing sangat efektif mendukung kegiatan pemasaran baik online maupun ofline.

e. Forum atau Komunitas Online

Forum adalah tempat diskusi untuk membahas sesuatu yang saat itu di butuhkan oleh konsumen, contoh dalam forum atau komunitas bisnis, anda harus secara aktif mengikuti forum- forum tersebut dengan tujuan mengenalkan diri kepada anggota-anggota lain terlebih dahulu, kemudian anda dapat meninggalkan link anda di forum tersebut.

f. Promosi melalui iklan gratis

Ini salah satu cara yang sering dilakukan oleh pelaku bisnis, saat ini banyak sekali situs di Indonesia yang menyediakan situs pasang iklan gratis tanpa mengeluarkan biaya, anda hanya perlu melakukan registrasi dan langsung memasukkan profil, dan rincian produk anda.

g. Pasang banner di situs lain

Memasang banner di situs yang memiliki banyak pengunjung lebih efektif karena hal tersebut dapat menarik pengunjung tersebut ke website anda, hal itu dapat membantu optimasi web anda.

h. Review produk

Review atau ulasan produk bisa jadi senjata yang ampuh dalam online marketing. Anda dapat meminta review dari blog lain tentang produk anda untuk menampilkan di blog atau website mereka.

i. Memberikan Respon 
Hal ini juga berpengaruh penting untuk kegiatan marketing. Ketika mendapat sebuah komentar ataupun balasan dari website, blog, atau yang lainnya dari para konsumen. Anda wajib segera membalasnya dengan tanggapan yang cukup hangat, respon yang kita berikan tentu menjadi salah satu alat yang efektif untuk meyakinkan konsumen tentang kepedulian atau pelayanan yang cukup besar terhadap permasalahan yang mereka hadapi.

\section{j. Mudah terindeks oleh mesin pencari GOOGLE}

Terakhir, ini untuk mengoptimalkan lagi dari cara-cara yang diatas yaitu cara jitu agar pesan promosi bisa cepat terindeks oleh mesin pencari GOOGLE. Contoh nya saja ketika kita menuliskan iklan pada twitter atau facebook jangan lupa mencantumkan hashtag (\#). Cara tersebut bertujuan untuk memudahkan twitter kita terindeks dalam mesin pencari dan berada pada posisi pertama ketika para pengguna twitter mencari keyword atau kata kunci yang kita gunakan.

\section{Metode Pengabdian Kepada Masyarakat}

Pengabdian Kepada Masyarakat ini dilakukan dalam bentuk pelatihan kepada pelaku usaha/industri kecil menengah di wilayah Bandung Raya melalui dua tahapan utama (Pra pelatihan dan Pelatihan), Pra Pelatihan melalui (1) survey terkait pelaku usaha industri kecil dan menengah di wilayah Kota Bandung Raya, yang perlu mendapatkan pelatihan internet marketing, dengan membaginya kedalam beberapa kategori baik sesuai jumlah permodalan, maupun kemampuan dalam pemanfaatan teknologi digital, (2) pembahasan dan pembuatan modul pemanfaatan internet marketing yang tepat bagi pelaku usaha/industri kecil dan menengah, dan pelatihan baik teori maupun praktek.

Materi pelatihan secara teori diberikan pemahaman terkait (1) Internet Marketing (2) Membangun Pemasaran Remix melalui internet (3) E-Model dan (4) ECustomers. Sedangkan pelatihan secara praktek dilakukan didepan komputer/notebook terhadap teori yang sudah diberikan dan dengan menggunakan perangkat lunak yang tersedia.

Pengabdian Kepada Masyarakat dalam upaya peningkatan kemampuan usaha kecil menengah di Wilayah Bandung Raya dalam pemanfaatan internet sebagai sarana pemasaran dan perluasan jangkauan pasar, akan dilakukan dalam bentuk pelatihan kepada pelaku usaha/industri kecil menengah di wilayah Bandung Raya melalui dua tahapan utama (Pra pelatihan dan Pelatihan), yaitu :

\section{Pra Pelatihan :}

1. Survey terkait pelaku usaha industri kecil dan menengah di wilayah Kota Bandung Raya, yang perlu mendapatkan pelatihan internet marketing, dengan membaginya kedalam beberapa kategori baik sesuai jumlah permodalan, maupun kemampuan dalam pemanfaatan teknologi digital.

2. Pembahasan dan pembuatan modul pemanfaatan internet marketing yang tepat bagi pelaku usaha/industri kecil dan menengah. 


\section{Pelatihan :}

\section{a. Teori}

1. Internet Marketing - Pendahuluan

a. Definisi dan cakupan internet marketing

b. Definisi dan cakupan $B 2 C, B 2 B, C 2 B$ dan $C 2 C$

c. Penjualan melalui internet

d. Pemanfaatan interet sebagai layanan konsumen

e. Pemanfaatan interet sebagai alat komunikasi

f. Pemanfaatan interet sebagai sarana untuk mengurangi ongkos

g. Pemanfaatan interet sebagai sarana membangun citra dan merk perusahaan

2. Membangun Pemasaran Remix melalui internet

a. Mix Marketing iand Remix Marketing

b. Membangun kerjasama melalui internet

3. E-Model
a. Definisi E-Models
b. Model-model E-Marketplace
c. Model online revenue
d. Model pembelian oleh konsumen

4. E-Customers
a. Motivasi, Ekspektasi dan kekhawatiran konsumen
b. Penelitian terhadap konsumen online
c. Proses pembelian online

\section{b. Praktek}

Praktek Internet Marketing di depan komputer/notebook dengan menggunakan perangkat lunak yang tersedia

\section{Pelaksanaan Kegiatan}

Pelaksanaan kegiatan Pengabdian Kepada Masyarakat (PKM) yang sudah dilakukan adalah sebagai berikut :

1. Melaksanakan persiapan dan kajian Literatur

a. Pendetailan terkait topik pelatihan

b. Pendetailan terkait pelaku usaha yang akan diundang sebagai peserta pelatihan

c. Pendetailan terkait tata cara penyampaian teori dan praktik yang akan dilakukan

d. Pendetailan terkait peneliti yang akan memberikan materi pelatihan.

e. Pemilihan literatur dan pembahasan yang akan dipilih sesuai dengan topik pelatihanantara lain :
i. E-Market Place
ii. E-Marketing
iii. Social Media Marketing

2. Melaksanakan diskusi dengan mitra, dan Dinas Perindustrian dan Perdagangan Provinsi;

a. Melakukan diskusi dengan Kepala Bidang Promosi Dinas Perindustrian dan Perdagangan Propinsi Jawa Barat terkait pelaku UKM yang memerlukan pelatihan pengembangan pasar melalui E-Market Place 
b. Melakukan diskusi dengan Ketua dan staff Cimahi Creative Association (CCA) terkait pelaku UKM yang memerlukan pelatihan pengembangan pasar melalui E-Market Place

3. Melakukan pembuatan dan pembahasan modul/materi pelatihan E-Market Place

a. Melakukan diskusi dan pendalaman materi dengan literatur yang sudah dipilih

b. Melakukan pembuatan modul untuk materi pelatihan

c. Melakukan simulasi terkait tata cara pelaksanaan pelatihan

d. Evaluasi materi dan tata cara pelaksanaan pelatihan.

4. Melaksanakan pelatihan

\section{Kesimpulan dan Saran}

Pelaksanaan pelatihan peningkatan kemampuan usaha kecil menengah di wilayah Bandung Raya dalam pemanfaaatan internet sebagai sarana pemasaran dan perluasan jangkauan pasar dapat terselenggara dengan baik de karena kerjasama berbagai pihak, baik dari tim peneliti maupun pemerintah kota dan Pemerintah Propinsi Jawa Barat yang sangat mendukung kegiatan ini, diikuti baik oleh pelaku UKM/IKM maupun perwakilan dari Dinas Industri dan Perdagangan seluruh Kabupaten/Kota di Propinsi Jawa Barat.

Diharapkan setelah pelatihan ini terbentuk forum komunikasi dan kerjasama pengembangan pasar melalui e-market place yang akan menjaga kesinambungan program ini dan mampu menumbuh kembangkan jejaring pasar industri /usaha kecil dan menengah khususnya industri kreatif baik di tingkat nasional maupun internasional, disertai dengan kesiapan penuh pada pengelolaan manajemen perusahaan berbasis elektronik.

\section{Daftar Pustaka}

Chaffey, Dave (2008). eMarketing eXcellence: Planning and Optimizing Your Digital Marketing, Elsevier Ltd.

Combe, Colin (2006). Introduction to E-Business : Management and Strategy, Elsevier Ltd.

Cassidy, Anita (2002). Planning for E-Business Success: How to E-Enable Your Enterprise, ST.Lucie Press.

Cornin, Martin (2002). eBusiness: Where Are We and Where Do We Go From Here?, Forfas.

Developers from DevZone (2011). Building eCommerce Applications, O'Reilly Media. Ian, B (2010). The latest in Search Marketing, Internet Advertising Bureau.

Kalakota \& Winsley (1997), E-Business Roadmap to Success, Addison Wesley

Kehal,Harbhajan S. (2005), Digital Economy: Impacts, Influence and Challenge, Idea Group Publishing.

Lachtnain Antoin (2007). Making an Impact Online, A\&C Black.

Lamersdof, Winfried (2004). Building the E-Service Society: E-Commerce, E-Business, and E-Government, Kluwer Academic Publishers.

Sawhney, Mohan (2001). The Seven Steps to Nirvana, McGraw Hill.

Weinberg, Tamar (2009). The New Community Rules : Marketing on The Social Web, O'Reilly.

W.S. Whyte (2001). Enabling E-Business: Integrating Technologies Architectures and Applications, John Wiley \& Sons Ltd. 